\title{
2020-2021 Vegetable Production Handbook: Chapter 1. Commercial Vegetable Production in Florida ${ }^{1}$
}

\author{
Josh H. Freeman, Peter J. Dittmar, and Gary E. Vallad ${ }^{2}$
}

Vegetable production remains a tremendous industry for Florida in terms of acreage and value. Including vegetables, melons, potatoes, and strawberries, production occurred on approximately 251,011 acres and generated more than $\$ 1.34$ billion in gross sales in 2016, which ranks second among all the states. Growing seasons are well defined by the peninsular geography, allowing Florida to serve as the main vegetable supplier during late fall, winter, and early spring months to the United States. Although more than 40 vegetable crops are commercially planted in the state, Florida ranks in the top three on production value of tomato, bell pepper, snap bean, squash, sweet corn, watermelon, cabbage, cucumber, and strawberry (Table 1.1).

Table 1.1. Vegetable production acreage and value in Florida.

\begin{tabular}{|l|l|l|l|}
\hline \multicolumn{1}{|c|}{ Crop } & \multicolumn{1}{|c|}{ Planted Acres } & \multicolumn{1}{c|}{$\begin{array}{c}\text { Value (million } \\
\text { US\$) }\end{array}$} & US Rank \\
\hline Tomato & 30,000 & 382.2 & 1 \\
\hline Strawberry & 10,800 & 449.7 & 2 \\
\hline Bell pepper & 13,500 & 209.7 & 2 \\
\hline Sweet corn & 37,600 & 160.0 & 2 \\
\hline Potato & 29,300 & 117.0 & 11 \\
\hline Snap bean & 28,200 & 105.6 & 1 \\
\hline Watermelon & 22,500 & 123.3 & 1 \\
\hline Squash & 6,000 & 30.0 & 2 \\
\hline Cabbage & 8,500 & 49.4 & 3 \\
\hline Cucumber & 11,000 & 66.0 & 1 \\
\hline Source: Vegetables-2015-2016 summary, NASS, USDA. & \\
\hline
\end{tabular}

1. This document is HS710, one of a series of the Horticultural Sciences Department, UF/IFAS Extension. Original publication date June 1995. Revised June 2020. Visit the EDIS website at http://edis.ifas.ufl.edu for the currently supported version of this publication.

2. Josh H. Freeman, associate professor, UF/IFAS North Florida Research and Education Center; Peter J. Dittmar, assistant professor, Horticultural Sciences Department; and Gary E. Vallad, associate professor, Plant Pathology Department, UF/IFAS Gulf Coast Research and Education Center; UF/IFAS Extension, Gainesville, FL 32611.

The Institute of Food and Agricultural Sciences (IFAS) is an Equal Opportunity Institution authorized to provide research, educational information and other services

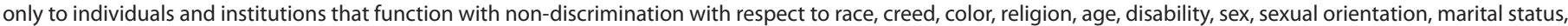

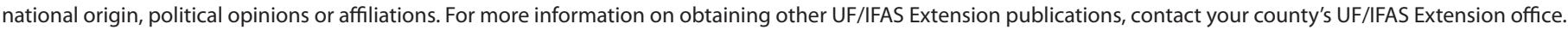
U.S. Department of Agriculture, UF/IFAS Extension Service, University of Florida, IFAS, Florida A \& M University Cooperative Extension Program, and Boards of County Commissioners Cooperating. Nick T. Place, dean for UF/IFAS Extension. 
Introduction to Organic Crop Production: https://edis.ifas. ufl.edu/cv118

Value Added Agriculture: Is It Right for Me?: https://edis. ifas.ufl.edu/fe638

Farm to School: https://edis.ifas.ufl.edu/

topic_farm_to_school

Row Covers for Growth Enhancement: https://edis.ifas.ufl. edu/cv201

\section{Fertility and Irrigation}

Commercial Vegetable Fertilization Principles: https:// edis.ifas.ufl.edu/cv009

Soil and Fertilizer Management for Vegetable Production in Florida: https://edis.ifas.ufl.edu/cv101

Controlled-Release and Slow-Release Fertilizers as Nutrient Management Tools: https://edis.ifas.ufl.edu/hs1255

Cover Crops: https://edis.ifas.ufl.edu/aa217

Principles and Practices of Irrigation Management for Vegetables: https://edis.ifas.ufl.edu/cv107

Drip Irrigation in the BMP Era: https://edis.ifas.ufl.edu/ hs 172

\section{Postharvest Quality and Handling Resources}

UF/IFAS Postharvest Quality \& Technology: https://irrec. ifas.ufl.edu/postharvest/

UF/IFAS EDIS (Electronic Data Information Source): https://edis.ifas.ufl.edu/topic_postharvest

Postharvest Technology: http://postharvest.ucdavis.edu

\section{Marketing and Regulatory Resources}

Florida Dept. of Agriculture \& Consumer Services (FDACS): https://www.freshfromflorida.com/ Divisions-Offices/Marketing-and-Development

US Grade Standards for Fruits and Vegetables: https:// www.ams.usda.gov/standards

National Agricultural Statistics Service: https://www.nass. usda.gov/fl/

National Nutrient Database: https://www.ars.usda.gov/
National Organic Program: https://www.ams.usda.gov/ nop/indexIE.htm

\section{Food Safety Resources}

Food Safety on the Farm: An Overview of Good Agricultural Practices: https://edis.ifas.ufl.edu/fs135

The Food Safety Modernization Act and the FDA Facility Registration Program: https://edis.ifas.ufl.edu/fs231

UF/IFAS Food Safety: https://edis.ifas.ufl.edu/ topic_food_safety/

Good Agricultural Practices Training: http://www.gaps. cornell.edu/

CDC: Division of Foodborne, Waterborne, and Environmental Diseases: https://www.cdc.gov/ncezid/dfwed/

FDA: US Food and Drug Administration: https://www. fda.gov/food/guidanceregulation/fsma/default.htm

\section{Fumigation}

Maximizing the Efficacy of Soil Fumigant Applications for Raised-Bed Plasticulture Systems in Florida: https://edis. ifas.ufl.edu/hs1169

\section{Pesticide Safety}

Pesticide Provisions of the Florida Agricultural Worker Safety Act (FAWSA): https://edis.ifas.ufl.edu/pi078

Pesticide Safety: https://edis.ifas.ufl.edu/cv108

Interpreting PPE Statements on Pesticide Labels: https:// edis.ifas.ufl.edu/pi137

Honeybees and Pesticides: https://edis.ifas.ufl.edu/in1027

\section{Pest Management}

Vegetable IPM. Integrated Disease Management for Vegetable Crops: https://edis.ifas.ufl.edu/pp111

Florida Nematode Management Guide: https://edis.ifas.ufl. edu/features/handbooks/nematode.html

Weed Management: https://edis.ifas.ufl.edu/cv113

Insects in Vegetables: https://edis.ifas.ufl.edu/ topic_vegetable_pest_insects 